\title{
Effects of dairy-products' consumption on sebum lipids and fatty acids
}

\author{
Y.Y. Al-Tamer *, A. A. Mahmood ** \\ * Department of Biochemistry, Nineveh College of Medicine; ** Department of Chemistry, College of \\ Education, University of Mosul.
}

(Ann. Coll. Med. Mosul 2009; 35(1): 18-25).

Received: $22^{\text {nd }}$ Jun 2008; Accepted: $25^{\text {th }}$ Jan 2009.

\begin{abstract}
Objectives: To investigate the effect of intake of dairy-products on the sebum lipid components and fatty-acid composition.

Patients and Methods: Sebaceous cysts were obtained, by simple surgery, from the scalp, face and neck of 21 men (aged 25-50 y) and divided into two groups. The first group included 11 cysts for subjects consuming dairy products and the second group included 10 cysts for subjects not consuming dairy products. Simple lipids, phospholipids (PLs), triglycerides (TGs), cholesterol (C), cholesterol ester (CE) and fatty acids (FAs) were removed by organic solvents extraction. The sebum lipid components, TGs and C, were determined enzymatically and PLs were determined using a colorimetric method based on the formation of a phosphomolybdate complex. Lipid components were separated by TLC. The separated components were hydrolyzed and their FAs were esterified by super dried-acidified methanol. Fatty-acid methyl esters were identified by capillary gas chromatography.
\end{abstract}

Results: Compared to the non-consumers group, the consumers group exhibited a significant increase in lipid contents, viz, PLs and C. Concerning the FA composition of CE, PLs and TGs, $n_{6^{-}}$ polyunsaturated FAs showed a higher percentage, viz. $C_{18: 2} n_{6}$ and $C_{9}, t_{11} C L A$, while $n_{3}$-polysaturated FAs showed a significant decrease, viz. $\mathrm{C}_{20: 5} \mathrm{n}_{3}$.

Conclusion: Consumption of dairy products affects the lipid content and the FA composition of sebum and C9,t11 Conjugated Linoleic Acid could be used as a marker for intake of dairy-product lipid.

\section{الخلاصة}

أهداف البحث: دراسة تأثثير تناول الحليب ومشتقاته على المواد الدهنية وتركيبة الأحماض الدهنية لمحتويات الأكياس

العينات وطرائق العمل: تم الحصول على أكياس دهنية استئصلت بجر احة بسيطة من مناطق مختلفة من الجسم (الر أس،

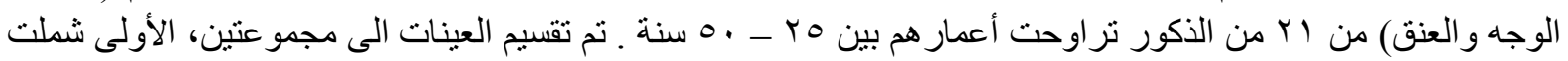

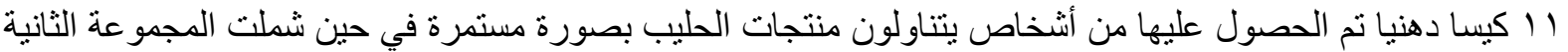

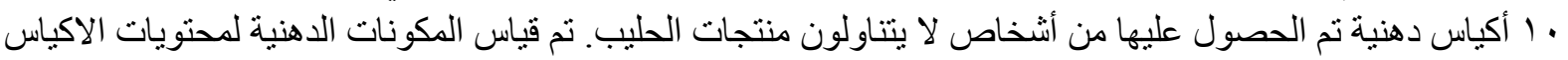

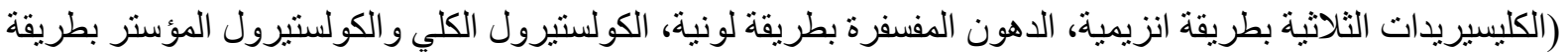

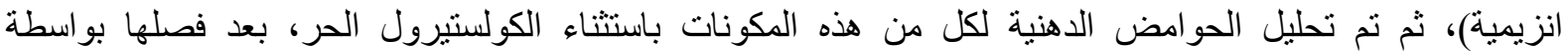

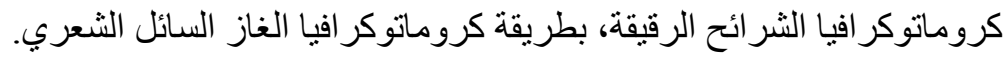


النتائـــج: بينت النتائج ان النماذج المأخوذة من أنخاص يتناولون منتجات الحليب تحتوي على نسب أعلى لجميع

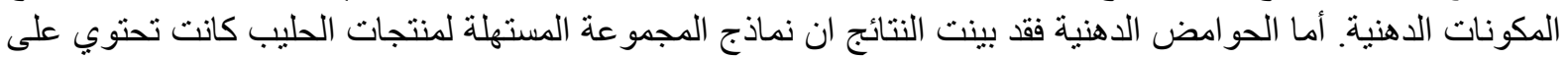

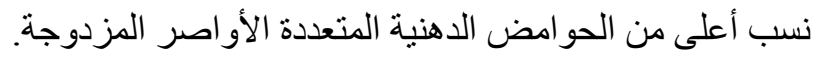

الاستتتاج: ان تناول منتجات الحليب يؤثر على المحتويات الدهنية ونركيب الأنئ الأحماض الدهنية للأكياس الدهنية ويعتبر

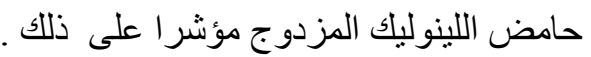

$\mathrm{T}$ he sebaceous follicle, in which the sebaceous gland is greatly enlarged, is filled with keratinous material, sebum, bacteria and fungi. The sebum secreted from sebaceous glands keeps the skin of the human body soft and oily ${ }^{(1,2)}$. Sebum is a complex lipid mixture and its complete chemical nature has not been fully elucidated and it varies widely from species to species ${ }^{(2,3)}$. Free fatty acids (FAs), triglycerides (TGs), cholesterol (C), cholesterol ester (CE), phospholipids (PLs), squalene, wax esters and paraffins have all been identified in sebum ${ }^{(4)}$.

The FA components have carbon chains up to $\mathrm{C}_{25}$ and they are both saturated and unsaturated, the latter being essential and non-essential $^{(3,5)}$. The characteristic features of hyperkeratosis and decreased barrier function in essential FA-deficiency can lead to plugging the follicle and it becomes distended by sebum, leading to the formation of sebaceous cysts $^{(6,7)}$. Sebaceous cysts occurs most frequently on the scalp, face and neck, though they appear on any part of the body ${ }^{(8,9)}$.

The components of sebum can be influenced by diet and hormones ${ }^{(1,4)}$. Dairy products contain a considerable amount of fat; more than $57 \%$ of its FAs are saturated, which is considered to be one of the common hypercholesterolemic factors ${ }^{(10,11)}$. Dairyproduct fat and meat from ruminants contain conjugated linoleic acid (CLA). The $\mathrm{Cis}_{9}$, trans $_{11}\left(\mathrm{C}_{9}, \mathrm{t}_{11}\right)$ is the major CLA isomer in dairy products $^{(11,12)}$. It is formed as a result of biohydrogenation reactions carried out by bacteria in the rumen, producing the precursor trans-11 octadecanoic acid (trans-vaccenic acid, tVA) and by $\Delta 9$ desaturase, that converts tVA to $\mathrm{C}_{9}, \mathrm{t}_{11} \mathrm{CLA}$, primarily in the mammary gland $^{(13,14)}$. Studies in animal models in which CLA intakes were increased showed antitumorigenic $\operatorname{activity}^{(15,16)}$, decreased atherogenesis $^{(17)}$, decreased adiposity and increased lean body mass ${ }^{(18)}$.

Concerning $\mathrm{n}_{3}$-polyunsaturated fatty acids (PUFAs), their percent in dairy-product fats are almost absent ${ }^{(19)}$.

In this study, we describe the effect of consuming large amounts of dairy products on the lipid content and on incorporation of $\mathrm{c}_{9}, \mathrm{t}_{11}$ CLA into sebum lipids of sebaceous cysts obtained from healthy men who were regular dairy-product consumers.

\section{Materials and methods}

The study was conducted on free-living subjects and was not strictly controlled for nutrient and energy intake but, in general, the subjects were divided into two groups. The first group (the consumers group) included subjects who usually consumed not less than $250 \mathrm{~g} /$ day of milk, yogurt or other dairy products. The second group (the nonconsumers group) included subjects who consumed less than $250 \mathrm{~g} /$ week of dairy products. It is worth noting that meat, the second source of CLA, was taken a few times a week by most of the Iraqi population owing to its high cost and money was scarce in the period of growth of the sebaceous cysts and doing this study (2002) as a result of the economic sanctions imposed on Iraq (19902003).

Sebaceous cysts were obtained by simple surgery (in Al-Jumhouri Hospital, Mosul) from the scalp, face and neck of 21 men, 25-50 year old, who were non-smokers and free from any apparent metabolic disorders. The samples were divided into two groups. The first group included 11 cysts for consumers and the second group included 10 cysts for non-consumers. The cysts were immediately put into sterile screw-capped vials containing 3 $\mathrm{ml}$ of methanol to limit the lipolytic and 
oxidative degradation of sebum-lipids before extraction $^{(20)}$.

\section{Extraction of sebum lipids}

Based upon their solubility characteristics, two types of sebum lipid were described: simple lipids which could be removed with organic solvents, and complex lipids that required more drastic extraction procedures. The former contained PLs, free FAs, free sterols, hydrocarbons, sterol esters and TGs ${ }^{5}$. In the present research, $0.5 \mathrm{~g}$ was weighed from each sebaceous cyst and then the simple lipids were extracted by a chloroform I methanol $(2: 1, V / V)$ mixture to a final dilution 1:20 W/V. The insoluble compounds in the homogenate were then removed by filtration ${ }^{(21)}$. The extract was mixed with $2 \mathrm{ml}$ of distilled water and the mixture was allowed to separate into two phases, by standing in a separating funnel(22). The lipid extract was evaporated (under nitrogen) to dryness, then the lipid was redissolved in $1 \mathrm{ml}$ of methanol.

\section{Lipid analysis}

Sebum lipid components, TGs and C, were determined enzymatically using kits obtained from bioMeriux, France. The PLs were determined by a colorimetric method based on the formation of a phosphomolybdate complex ${ }^{(23)}$. Thin layer chromatography was applied to separate the lipid components, TGs, PLs and CEs using Merck silica gel G 0.25 $\mathrm{mm}$ and hexane: diethyl ether: formic acid mixture( $80: 20: 2$ by volume). After drying, the plates were sprayed with $1 \%$ alcoholic solution of 2,7-dichlorofluorescin (a non-destructive agent) to visualize each band under UV-light. The separated components were scraped into separate vials and stored at $-20^{\circ} \mathrm{C}$, then their FAs moiety was converted to fatty acid methyl esters (FA-MEs) by super dried-acidified methanol at $90-95{ }^{\circ} \mathrm{C}$ for $2 \mathrm{~h}^{(20)}$. The proportional composition (\%) of methylated fatty acids was determined by capillary gas chromatography. The samples were analyzed in the National Centre for Scientific Research (CNRS), the Institute of Chemistry of Natural Substances (ICSN), France. The capillary gas chromatograph was CP-3800, Varian, USA. The capillary column was CP-Sil $8 \mathrm{CB}, 0.25$ $\mathrm{mm}$ LD $\times 30 \mathrm{~m}$ with film thickness: $0.25 \mathrm{~mm}$ and helium as carrier gas. The programme used a temperature gradient from 80 to 220 ${ }^{\circ} \mathrm{C}, 5{ }^{\circ} \mathrm{C}$ for each min. The identity of 14 individual FA-peaks was ascertained by comparing each peak's retention time relative to the retention times of FAs in synthetic standards. The relative amount of each FA (\% of total FAs) was quantified by integrating the area under the peak and dividing the result by the total area for all FAs. To minimize transcription errors, the data from the gas chromatogram were electronically transferred to a computer for analysis.

\section{Statistical Analysis}

The t-test was used to compare the means for the two groups in terms of the lipid components and FA composition of the sebum of sebaceous cysts. All the data were expressed as mean \pm standard deviation. Pvalues $\leq 0.05$ were considered significant.

\section{Results}

\section{a. Sebum lipid components:}

Figure (1) shows the relation between the amount of general classes of simple lipids (C, PLs and TGs) in the sebum of sebaceous cysts of two groups of subjects, dairy-product consumers and non-consumers. The average amounts of C, PLs and TGs were 18.96 and $26.17 \mathrm{mg} / \mathrm{g}, 11.61$ and $15.29 \mathrm{mg} / \mathrm{g}$ and 4.35 and $4.44 \mathrm{mg} / \mathrm{g}$ of cysts, respectively. These results indicate that the consumers group showed a significantly higher level of $\mathrm{C}$ and PLs in contrast to the non-consumers group, but there was no significant difference in the amount of TGs.

\section{b. Sebum fatty-acid composition:}

Fatty acid composition of sebum-lipid components (CE, PLS and TGs) for the two groups of subjects were shown in Tables a,b,c:

\section{i. Sebum-CE fatty acids:}

The consumers group, compared with the non-consumers group, (Table a) showed a significant decrease in saturated fatty acids (SFAs). Both groups, however, showed a low level of medium-chain fatty acids (MCFAs), $\mathrm{C}_{10}-\mathrm{C}_{14}$, and a high level of $\mathrm{C}_{16}$ and $\mathrm{C}_{18}$. Concerning monounsaturated fatty acids 
(MUFAs), $\quad \mathrm{C}_{16: 1}$ and $\mathrm{C}_{18: 1}$, there was a significant decrease in the consumers group. As regards the polyunsaturated fatty acids (PUFAs), $\mathrm{C}_{18: 2} \quad \mathrm{n}_{6}$ and $\mathrm{C}_{9}, \mathrm{t}_{11}$ CLA showed higher percentages for the consumers group, but the other PUFAs exhibited lower percentages. The Table showed a significant decrease in $n_{3}$-FAs for the consumers group.

\section{ii. Sebum-PL fatty acid:}

As shown in Table (b), PLs exhibited a nonsignificant decrease in SFAs for the consumers group. The relative amount of $C_{18: 1}$ for the consumers group was significantly lower than that for the non-consumers group, while $C_{16: 1}$ was nearly absent in both groups. As regards PUFAs, $\mathrm{C}_{18: 2} \mathrm{n}_{6}$ and $\mathrm{C}_{9}, \mathrm{t}_{11}$ CLA showed higher percentages for the consumers group but the other PUFAs showed lower percentages. There was a significant decrease in $n_{3}$-FAs for the consumers group compared with the non-consumers group.

\section{iii. Sebum-TGs fatty acids:}

Table (c) showed no significant difference in the percentages of SFAs and MUFAs for the two studied groups. As regards PUFAs, the consumers group exhibited a decrease in their level except for $c_{9}, t_{11} C L A$ and, to some extent, $\mathrm{C}_{18: 2} \mathrm{n}_{6}$. As in the case of CE and PLs, TGs showed a significant decrease in $n_{3}$-FAs for the consumers group compared with the nonconsumers group.

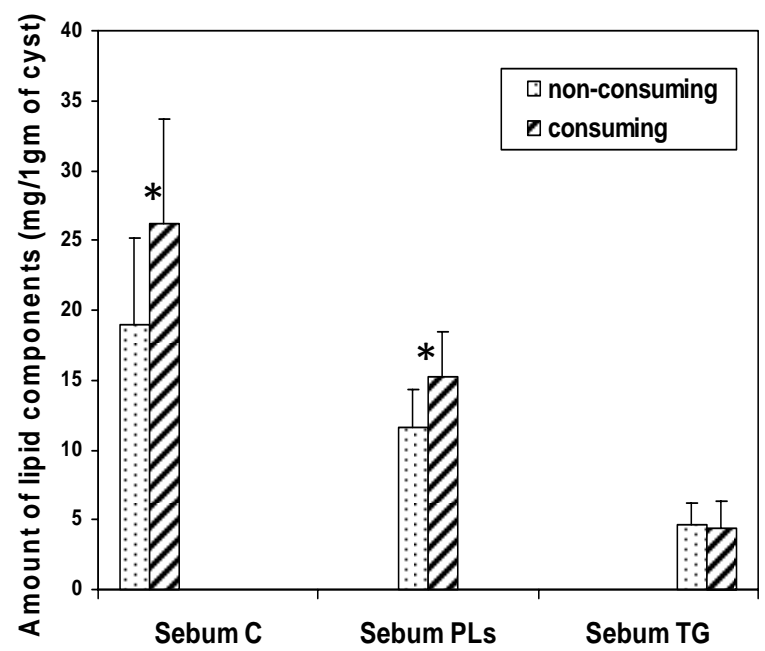

Fig (1): Comparison between the amount of sebum lipid components of sebaceous cysts of subjects non-consuming and consuming dairy products

$\mathrm{C}=$ cholesterol, $\mathrm{PLS}=$ phospholipids, $\mathrm{TGs}=$ triglycerides

* Significant difference at $p \leq 0.05$

Table: Sebum-lipid fatty acid composition of subjects consuming and non-consuming dairy products

(a) Sebum CE-fatty acid composition (wt $\%)$

\begin{tabular}{|c|c|c|}
\hline \multirow{2}{*}{ Fatty acid } & \multicolumn{2}{|c|}{ Mean \pm SD } \\
\hline & Non-consumer & Consumer \\
\hline \multicolumn{3}{|l|}{ Saturated } \\
\hline $10: 0$ & $0.06 \pm 0.03$ & $0.05 \pm 0.03$ \\
\hline $12: 0$ & $1.02 \pm 0.01$ & $1.14 \pm 0.29$ \\
\hline $14: 0$ & $1.56 \pm 0.40$ & $1.50 \pm 0.33$ \\
\hline $16: 0$ & $12.42 \pm 0.77$ & $12.13 \pm 1.13$ \\
\hline $18: 0$ & $6.99 \pm 1.05$ & $5.67 \pm 1.06^{\star}$ \\
\hline Total & $22.05 \pm 1.07$ & $20.49 \pm 1.43^{*}$ \\
\hline \multicolumn{3}{|c|}{ Monounsaturated } \\
\hline $16: 1$ & $1.12 \pm 0.15$ & $0.82 \pm 0.11^{*}$ \\
\hline $18: 1$ & $20.95 \pm 0.66$ & $18.11 \pm 1.39 *$ \\
\hline Total & $22.07 \pm 0.63$ & $18.94 \pm 1.40 *$ \\
\hline \multicolumn{3}{|c|}{ Polyunsaturated } \\
\hline $18: 2$ n6 & $45.5 \pm 4.13$ & $52.81 \pm 4.41^{*}$ \\
\hline $18: 3$ n6 & $1.45 \pm 0.39$ & $0.74 \pm 0.06^{\star}$ \\
\hline $18: 3$ n3 & $0.46 \pm 0.06$ & $0.36 \pm 0.13^{\star}$ \\
\hline $20: 4$ n6 & $6.79 \pm 0.77$ & $5.29 \pm 0.78^{\star}$ \\
\hline $20: 5$ n3 & $0.62 \pm 0.07$ & $0.33 \pm 0.06 *$ \\
\hline $22: 6$ n3 & $0.62 \pm 0.07$ & $0.42 \pm 0.09 *$ \\
\hline $18: 2 c_{9}, t_{11}$ & $0.44 \pm 0.02$ & $0.62 \pm 0.04^{*}$ \\
\hline n3 & $1.70 \pm 0.13$ & $1.12 \pm 0.13^{\star}$ \\
\hline n6 & $53.74 \pm 4.50$ & $58.84 \pm 4.91$ \\
\hline
\end{tabular}

$* p \leq 0.05=$ significant difference 
(b) Sebum PL-fatty acid composition (wt\%)

\begin{tabular}{|c|c|c|}
\hline \multirow{2}{*}{ Fatty acid } & \multicolumn{2}{|c|}{ Mean \pm SD } \\
\hline & $\begin{array}{c}\text { Non- } \\
\text { consumer }\end{array}$ & Consumer \\
\hline \multicolumn{3}{|l|}{ Saturated } \\
\hline 10:0 & $0.10 \pm 0.04$ & $0.13 \pm 0.05$ \\
\hline $12: 0$ & $1.64 \pm 0.35$ & $0.98 \pm 0.37^{\star}$ \\
\hline $14: 0$ & $1.38 \pm 0.44$ & $1.31 \pm 0.38$ \\
\hline 16:0 & $25.91 \pm 4.59$ & $23.24 \pm 4.45$ \\
\hline 18:0 & $14.95 \pm 1.87$ & $14.83 \pm 2.54$ \\
\hline Total & $43.97 \pm 5.89$ & $40.50 \pm 6.19$ \\
\hline \multicolumn{3}{|c|}{ Monounsaturated } \\
\hline $16: 1$ & $0.02 \pm 0.02$ & $0.02 \pm 0.02$ \\
\hline 18:1 & $9.31 \pm 1.15$ & $7.54 \pm 1.37^{\star}$ \\
\hline Total & $9.33 \pm 1.14$ & $7.56 \pm 1.37^{*}$ \\
\hline \multicolumn{3}{|c|}{ Polyunsaturated } \\
\hline $18: 2$ n6 & $27.44 \pm 4.18$ & $36.02 \pm 4.42^{\star}$ \\
\hline 18:3 n6 & $0.18 \pm 0.04$ & $0.18 \pm 0.06$ \\
\hline $18: 3$ n3 & $0.17 \pm 0.05$ & $0.21 \pm 0.06$ \\
\hline $20: 4$ n6 & $11.43 \pm 3.34$ & $9.23 \pm 4.04$ \\
\hline $20: 5$ n3 & $0.86 \pm 0.16$ & $0.45 \pm 0.14^{*}$ \\
\hline $22: 6$ n3 & $6.11 \pm 0.97$ & $5.16 \pm 1.3$ \\
\hline $18: 2 \mathrm{c}_{9}, \mathrm{t}_{11}$ & $0.51 \pm 0.03$ & $0.69 \pm 0.04^{*}$ \\
\hline n3 & $7.13 \pm 0.95$ & $5.82 \pm 1.31^{*}$ \\
\hline n6 & $30.63 \pm 6.47$ & $38.81 \pm 6.10^{*}$ \\
\hline
\end{tabular}

* $p \leq 0.05=$ significant difference (c) Sebum TG-fatty acid composition (wt\%)

\begin{tabular}{|c|c|c|}
\hline \multirow{2}{*}{ Fatty acid } & \multicolumn{2}{|c|}{ Mean \pm SD } \\
\hline & $\begin{array}{c}\text { Non- } \\
\text { consumer }\end{array}$ & Consumer \\
\hline \multicolumn{3}{|l|}{ Saturated } \\
\hline 10:0 & $0.29 \pm 0.04$ & $0.38 \pm 0.09^{*}$ \\
\hline $12: 0$ & $0.19 \pm 0.03$ & $0.38 \pm 0.05^{\star}$ \\
\hline $14: 0$ & $2.22 \pm 0.61$ & $2.25 \pm 0.5$ \\
\hline 16:0 & $24.46 \pm 4.86$ & $21.96 \pm 4.04$ \\
\hline 18:0 & $4.26 \pm 0.51$ & $7.01 \pm 0.72^{*}$ \\
\hline Total & $31.42 \pm 5.11$ & $31.98 \pm 4.32$ \\
\hline \multicolumn{3}{|c|}{ Monounsaturated } \\
\hline $16: 1$ & $2.38 \pm 0.48$ & $2.35 \pm 0.52$ \\
\hline 18:1 & $25.26 \pm 5.59$ & $23.12 \pm 4.46$ \\
\hline Total & $27.64 \pm 5.61$ & $25.47 \pm 4.59$ \\
\hline \multicolumn{3}{|c|}{ Polyunsaturated } \\
\hline $18: 2 \mathrm{n} 6$ & $26.01 \pm 5.25$ & $30.73 \pm 3.89$ \\
\hline $18: 3 \mathrm{n} 6$ & $0.71 \pm 0.13$ & $0.68 \pm 0.08$ \\
\hline 18:3 n3 & $0.91 \pm 0.42$ & $1.09 \pm 0.33$ \\
\hline $20: 4$ n6 & $7.32 \pm 1.29$ & $5.53 \pm 1.22^{\star}$ \\
\hline $20: 5$ n3 & $1.14 \pm 0.29$ & $0.59 \pm 0.15^{\star}$ \\
\hline $22: 6$ n3 & $4.64 \pm 1.46$ & $3.60 \pm 1.35$ \\
\hline $18: 2 \mathrm{c}_{9}, \mathrm{t}_{11}$ & $0.21 \pm 0.04$ & $0.33 \pm 0.04^{*}$ \\
\hline n3 & $6.69 \pm 1.38$ & $5.28 \pm 1.28^{*}$ \\
\hline n6 & $34.04 \pm 5.32$ & $36.94 \pm 7.76$ \\
\hline
\end{tabular}

${ }^{*} \mathrm{p} \leq 0.05=$ significant difference 


\section{Discussion}

\section{a. Sebum lipid components:}

As shown in the figure (1), the level of $C$ was higher in the consumers-group. The increase in the level of sebum $C$ might be affected by the increase of its level in serum since the habit of consuming large quantities of dairy products leads to increased serum- $C$ level. The dairy-product lipids include the main cholesterolemic SFAs; $\mathrm{C}_{12}, \mathrm{C}_{14}$ and $\mathrm{C}_{16}{ }^{(24)}$; and the stratum basale is equipped with the LDL-receptors that allow the potential uptake of cholesterol. On the other hand, essentialfatty acid (EFAs) deficiency leads to increase cholesterol synthesis by affecting the activity of HMG-CoA reductase (cholesterol rate-limiting enzyme $)^{(5,19)}$.

Concerning the sebum PLs, they exhibited a higher level in the consumer group, which reflects the fact that high-fat diets, including dairy products, tend to increase PLs ${ }^{(23,24)}$. This seems to be in harmony with what Mahmood (2002) states about the serum PLs of subjects who consume dairy products.

As figure (1) shows, there is no significant difference in the level of sebum TGs between the two groups. This indicates that the effect of dairy-product consumption on the level of sebum TGs was almost absent. Although about $99 \mathrm{wt} \%$ of human adipose tissue-lipids consisted of $\mathrm{TGs}^{(22)}$, the percentage of sebum TGs was much lower in this and other studies $^{(4)}$.

\section{b. Sebum fatty-acid composition:}

The SFAs of CE of dairy-product consumers exhibited a decrease in their amount compared with that of the non-consumers group as shown in Table (a). This indicates that dairy-product SFAs do not affect the sebum SFAs since they are synthesized in $\operatorname{situ}^{19,25}$. The results obtained for the SFAs of PLs and TGs, when there was no significant difference in their percentage for both groups, seem to agree with this explanation. The Table shows a lower percentage of MUFAs for CE, PLs and, to some extent, TGs although dairyproduct lipid contains a high proportion of oleic $\operatorname{acid}^{(26,27)}$. The negative correlation may be attributed to either the consumption of other sources of the diet by the two groups or to the enzymatic competition for desaturases and elongases during the endogenous synthesis ${ }^{(24)}$. Generally, when analyzing the FA composition of tissue samples to estimate the FA composition of the diet, strong correlations have been found between EFAs and the estimated dietary intake. Correlations for nonessential unsaturated and saturated FAs are weaker ${ }^{(9,28)}$.

Consumption of dairy products increases the level of $C_{18: 2} n_{6}$ in the body ${ }^{(19,29)}$ and this mimics the result listed in the table. In addition, there was a negative relationship between the amount of MUFAs $\left(\mathrm{C}_{16: 1}\right.$ and $\left.\mathrm{C}_{18: 1}\right)$ and the amount of $\mathrm{C}_{18: 2}$ of sebum ${ }^{(5)}$.

The consumers group showed a significant decrease in $\mathrm{C}_{20: 5} \mathrm{n}_{3}$ and $\mathrm{C}_{22: 6} \mathrm{n}_{3}$. This might be due to the high level of $C_{18: 2} n_{6}$ of this group which modulates the action of 5-desaturase under the control of hormonal factors. Furthermore, $\mathrm{C}_{18: 3} \mathrm{n}_{6}$ and $\mathrm{C}_{20: 4}$ were also lower in the consumers group probably due to the same effect of the high level of linoleic $\operatorname{acid}^{(25,30,31)}$. Dairy-product lipid seems to decrease $n_{3}$-FAs and increase $\mathrm{n}_{6}$-FAs in sebum lipid as shown in the Table, and it is worth mentioning that the balance between the level of $n_{3}$ and $n_{6}$-FAs is important because of the competitive nature of their different biological roles ${ }^{(5,32,33)}$.

As regards CLA, the concentration of $\mathrm{c}_{9}, \mathrm{t}_{11}$ which is the major CLA isomer in the diet ${ }^{(13)}$, probably reflects habitual intakes ${ }^{(12)}$. The present study showed that consuming dairy products naturally enriched in CLA, especially $\mathrm{C}_{9}, \mathrm{t}_{11} \mathrm{CLA}$, increases its concentration in all the studied sebum components. The positive association in the concentration of $\mathrm{C}_{9}, \mathrm{t}_{11}$ CLA between $C E$ and $P L$ might reflect the synthesis of $C E$ from $P L$, particularly phosphatidylcholine by lecithin: cholesterol acyl transferase activity ${ }^{(12,19)}$. The FA composition of human adipose tissues reflects, to a great extent, the average distribution of the dietary FAs over a period of $2-3 y^{(22)}$ and it has been found that CLA is present principally in ruminant-animal food products' mainly dairy products ${ }^{(14)}$.

In conclusion, the high consumption of dairy products affects sebum lipid contents and fatty 
acid composition mainly $\mathrm{c}_{9}, \mathrm{t}_{11}$ CLA so it can be used as a marker for the intake of dairyproduct lipid. These findings are in agreement with a recent report ${ }^{(34)}$, which showed a dietary influence on the sebaceous lipogenesis.

\section{Acknowledgement}

We thank the French Embassy for granting a research fellowship for the analysis of samples by capillary gas chromatography, since this technique is not available in Iraq at the present time. We would also like to express our gratitude to Dr. Christain Marazano, Dr. Stephane Mons, Dr. Alice Olsker and Wafaa Al-Sheikh, the staff of the Laboratory of CNRS, France, who provided the facilities for the analysis performed. The cooperation of the volunteers and the nursing staff of Al-Jumhouri Hospital is sincerely acknowledged.

\section{References}

1. Vasarinsh MD. Clinical Dermatology. Butterworth Publishers, London, 1982; p.9.

2. Fitzpatrick TB, Clark $W H$, Eisen $A Z$, Van Scott EJ, Arndt KA, Vauqhan JH. Dermatology in General Medicine. McGraw Hill Book Company, London,1971; pp. 353-355.

3. Rook A, Wilkinson DS, Ebling FJG. . Textbook of Dermatology. Blackwell Scientific Publications, Oxford, Vol. 2, $3^{\text {rd }}$ ed.,1979; pp. 1693-1996.

4. Stewart ME. Sebaceous gland lipids. Semin Dermatol 1992;11, 100-105.

5. Norwegian Elkhound Association of America (Internet) Sebaceous Cysts Versus Intracutaneous Cornifying Epithelioma .2000; NEAA Canine Health and Research Committee. (www.neaa.net)

6. Schrer NY, Elias PM. The Biochemistry and Function of Stratum Corneum Lipids. Adv. Lipid Res. 1991; (24)27, 27-56.

7. Sneddon IB, Church RE . Practical Dermatology. Bulter and Tanner Ltd., London, $4^{\text {th }}$ ed. 1985; pp. 204-205.

8. Naik NS. Steatocystoma multiplex. Dermatology Online J. 2000; (6)1: 10.

9. Smedman AEM, Gustafsson IB, Berglund LGT and Vessby BOH. Pentadecanoic acid in serum as a marker for intake of milk fat: relations between intake of milk fat and metabolic risk factors. Am. J. Clin. Nutr. 1999; 69(1): 22-29.

10. Denke MA and Grundy SM. Comparison of effects of lauric acid and palmitic acid on plasma lipids and lipoproteins. Am. J. Clin. Nutr. 1992; 56: 895-898.

11. Burdge GC, Tricon S, Morgan R, Kliem $\mathrm{KE}$, Childs C, Jones E, Russell JJ ,Grimble RF , Williams CM , Yaqoob P and Calader PC . Incorporation of cis9, trans11 conjugated linoleic acid and vaccenic acid (trans-11 18:1) into plasma and leucocyte lipids in healthy men consuming dairy products naturally enriched in these fatty acids. Br. J. Nutr. 2005; 94: 237-243.

12. Burgde, GC, Lupoli B, Russell JJ, Tricon $\mathrm{S}$, Kew S, Banerjee $\mathrm{T}$, Shingfield $\mathrm{KJ}$, Beever DE, Grimble RF, Williams CM , Yaqoob P and Calder PC. Incorporation of cis-9, trans-11 or trans-10, cis-12 conjugated linoleic acid into plasma and cellular lipids in healthy men. J. Lipid Res. 2004; 45: 736-741.

13. Lawson RE, Moss AR, Givens DI. The role of dairy products in supplying conjugated linoleic acid to man's diet: a review. Nutr. Res. 2001; 14: 53-172.

14. Kelly ML, Berry JR, Dwyer DA, Griinari JM, Chouinard PY, Van Amburgh ME, Bauman DE. Dietary fatty acid sources affect conjugated linoleic acid concentrations in milk from lactating dairy cows. J. Nutr. 1998; 128: 881-885.

15. Belury MA. Inhibition of carcinogenesis by conjugated linoleic acid: potential mechanisms of action. J. Nutr. 2002; 132: 2995-2998.

16. Jensen RG, Lammi-Keefe CJ, Hill DW, Kind AJ, Henderson R. The anticarcinogenic conjugated fatty acid, 9c, 11t-18:2 in human milk: conformation of its presence. J. Hum. Lact. 1998; 14(1): 2327.

17. Munday JS, Thompson KG, James KA. Dietary conjugated linoleic acid promote fatty streak formation in the C57BL/6 mouse atherosclerosis model. $\mathrm{Br}$. J. Nutr. 1999; 81: 251-255.

18. West DB, Delany JP, Camet PM, Blohm F, Truett AA, Scimeca J. Effects of 
conjugated linoleic acid on body fat and energy mechanism in the mouse. Am. J. Physiol. 1998 ; 275: R667-R672.

19. Mahmood AA. Lipid components and fatty acid composition of human serum of subjects consuming dairy products. Ph.D. Thesis, Univ. of Mosul, Mosul-Iraq. 2002.

20. Al-Tamer YY, Mahmood AA. Fatty acid composition of the colostrum and serum of fullterm and preterm delivery Iraqi mothers. E.J. Clin. Nutr. 2004; 58: 11191124.

21. Folch J, Lees M, Sloane-Stanely GH. A Simple method for the isolation and purification of total lipids from animal tissues. J. Biol. Chem. 1957; 226: 497509.

22. Bysted A., Cold S, Holmer G. An optimized method for fatty acid analysis, including quantification of trans fatty acids in human adipose tissue by gas-liquid chromatography. Scand. J. Clin. Lab. Invest. 1999; 59: 205-214.

23. Tietz, N.W. Textbook of Clinical Biochemistry. W.B. Saunders Co., Philadelphia, 1986; USA, p. 135.

24. Al-Tamer YY, Mahmood AA. Lipid components and fatty acid composition of Iraqi subjects who smoke and consume dairy products. Nutr. Metab. Cardiovasc. Dis. 2004; 14: 94-96.

25. FAO/WHO. Fats and Oils in Human Nutrition. Report of Joint Expert Consultation. FAO, Rome; FAO Food and Nutrition, 1994; 57.

26. Hegsted DM, Ausman LM, Johnson JA, Dallal GE. Dietary fat and serum lipids. Am. J. Clin. Nutr. 1993; 57: 875-883.
27. Mensink RP, Katan MB. Effect of dietary fatty acids on serum lipids and lipoproteins. A meta-analysis of 27-trials. Atherosclerosis Throm. 1992; 12: 911-919.

28. London SJ, Sacks FM, Caesar J, Stampfer MJ, Siguel E, Willett WC. Fatty acid composition of subcutaneous adipose tissue and diet in post menopausal US women. Am. J. Clin. Nutr. 1991; 54: 340345.

29. Raatz SK, Bibus D, Thomas W, Etherton PK. Total fat intake modifies plasma fatty acid composition in humans. Am. J. Nutr. 2001; 131: 231-234.

30. Innis SM. Essential fatty acid requirements in human nutrition. Can. Physiol. Pharmacol. 1993; 71: 699-705.

31. Fisher S. Dietary poorly unsaturated fatty acids and eciosanoid formation in humans. Adva. in Lipid Res. 1989; 23: 169-198.

32. Minihane AM, Leigh-Fribank EC, Leak DS, Wright JW, Murphy MC, Griffin BA.. Eicosapentaenoic acid and docosahexaenoic acid from fish oils: differential associations with lipid responses. Brit. J. Nutr. 2002; 87(5): 435445.

33. Von-Schacky C. n-3 fatty acids and the preventation of coronary atherosclerosis. Am. J. Clin. Nutr. 2000; 71(1): 224-227.

34. Smith RN, Braue A, Varigos GA, Mann NJ. The effect of a low glycemic load on acne vulgaris and the fatty acid composition of skin surface triglycerides. J Dermatol Sci. $2008 ; 50: 41$ - 52 . 